\title{
Cathionic corrosion inhibitors for protection of steel in chloride containing concrete pore solution
}

\section{Katiónové korózne inhibítory na ochranu ocele v pórovom roztoku betónu s obsahom chloridov}

\author{
Lovasi T., Kouril M., Jamborova T., Stoulil J., Msallamova S. \\ Department of Metals and Corrosion Engineering, UCT Prague \\ E-mail: kourilm@vscht.cz
}

\begin{abstract}
Electrochemical chloride extraction from a reinforced concrete structure may be accompanied with an electrochemical injection of healing agents if such agents are positively charged and are able to migrate towards the activated reinforcement. Positive charge carried by nanoparticles or cathionic corrosion inhibitors might be the proper choice. Organic substances with a positive charge and their salts are mostly such inhibitors. The essential conditions for successful application of such corrosion inhibitors are their sufficient corrosion inhibition efficiency that was studied and evaluated and their stability of positive charge in chloride containing concrete pore solution.
\end{abstract}

\section{INTRODUCTION}

Concrete is a versatile building material, used for both the load-bearing structures (skeletons) and the production of panels; in the construction industry, concrete is the main material for the construction of bridges, roads of the motorways; in underground construction concrete is used as a temporary and permanent reinforcement. Optimum features, minimal maintenance, low cost and high service life make this material suitable for use on transport roads. For all of these applications, concrete is used as a composite, reinforced concrete. Reinforced concrete is made of concrete and steel reinforcement, which is embedded in the concrete to make it "stretched" when the element is deformed (load). The reason for inserting reinforcement into concrete is typical properties of concrete, i.e. high compressive strength but very low tensile strength. In contrast, the reinforcement has a good tensile strength. On the other hand, the disadvantage of steel is, on the contrary, its limited corrosion resistance and serious deterioration of structures as a result of steel reinforcement corrosion. The cement paste in the concrete provides an alkaline environment that protects steel against corrosion. This corrosion resistance is
Elektrochemická extrakcia chloridov zo železobetónovej konštrukcie môže byt' sprevádzaná s elektrochemickou injektážou hojivých látok, ak sú tieto látky pozitivne nabité a sú schopné migrovat'smerom k aktivovanej výstuži. Nanočastice nesúce pozitívny náboj alebo katiónové korózne inhibitory môžu byt' tou správnou vol'bou. Organické látky s kladným nábojom a ich soli najčastejšie zastávajú úlohu takýchto inhibitorov. Základné podmienky pre úspešnú aplikáciu takýchto koróznych inhibitorov sú ich dostatočná inhibičná účinnost', ktorá bola študovaná a vyhodnotená spolu so stabilitou kladného náboja $v$ pórovom roztoku betónu s obsahom chloridov.

due to passive film that forms on the steel when it is embedded in fresh concrete. This passive layer is stable in high alkaline environment. The $\mathrm{pH}$ of such an environment ranges from 12.5 to 14 [1]. Steel in this state has adequate corrosion resistance and negligible corrosion rate. To break this condition, the passive layer must be damaged. The two main reasons for breaking the passive layer are attack by chloride ions or concrete carbonation. The chlorides may originate from seawater and de-icing salt [2]. Carbonatation is a chemical reaction (1) in which calcium hydroxide reacts with carbon dioxide and forms insoluble calcium carbonate $[3,4]$ resulting in $\mathrm{pH}$ drop:

$$
\mathrm{Ca}(\mathrm{OH})_{2}(\mathrm{aq})+\mathrm{CO}_{2}(\mathrm{aq}) \rightarrow \mathrm{CaCO}_{3}(\mathrm{~s})+\mathrm{H}_{2} \mathrm{O}
$$

Chloride-induced corrosion can be mitigated by reducing the chloride ion level in concrete by various mechanisms $[5,6]$. Cathodic prevention is one of the most used techniques [7-10]. Another option is realkalization [11]. Modern treatment of reinforced concrete structure includes electrochemical chloride extraction and electrochemical injection of corrosion inhibitor [12-18]. Regarding the electrochemical injection, there is the possibility of corrosion inhibitors feeding into concrete. An applicability of such an inhibitor is limited by 
certain conditions. One of the basic conditions is to provide adequate protection in chloride contaminated environment. The second important condition is to exist predominantly in a cationic form in an aqueous medium under the given conditions [19]. There are many corrosion inhibitors tested in the literature, an example may be corrosion inhibitors based on amines and alkanolamines.

The aim of this study was to investigate the corrosion inhibition efficiency of several corrosion inhibitors with prospectively cathionic action in two model solutions.

\section{EXPERIMENT}

\section{Steel specimens}

The carbon steel (1.0330) was used as the tested material for the individual tests. It is ferritic-perlitic steel (Fig. 1) containing elements: 0,045\% C, 0,382 \% Mn, $0,007 \%$ P, 0,009 \% S [20]. This carbon steel was cut in the form of strips $(35 \times 175 \mathrm{~mm})$. Subsequently, these strips were degreased with a $10 \%$ sodium hydroxide solution. Subsequently, pickling with a 5\% hydrochloric acid, and thoroughly washed with distilled water afterwards. The surface was polished with emery paper P180 and rinsed with ethanol prior to exposure.

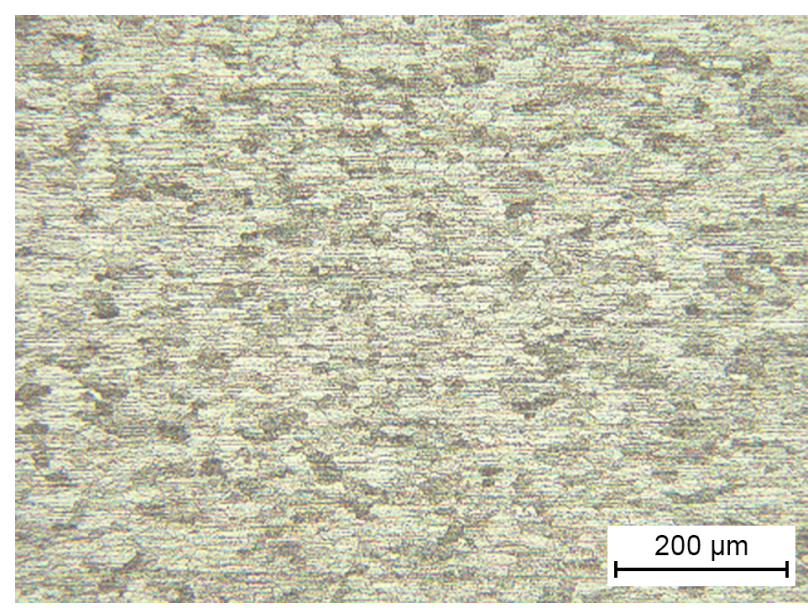

Fig. 1. Microstructure of carbon steel Obr. 1. Mikroštruktúra uhlíkovej ocele

\section{Corrosion inhibitors}

The effectiveness of several corrosion inhibitors, which could subsequently be used for electrochemical injection, has been tested. For making the testing solutions, following chemicals have been used: Guanidine carbonate (GA) $99 \%$; Methylamine (MA), extra pure, $40 \mathrm{wt} \%$ solution in water and Tetrabutylammonium bromide (TBAB), $99 \%$.

\section{Model solutions}

Two model environments were used to test the efficiency of individual corrosion inhibitors. As a model solution, a saturated solution of calcium carbonate with $\mathrm{pH}$ value of 8 was used to simulate the environment of carbonated concrete. Sodium chloride was added to the solution at various concentrations. The other solution, a concrete pore solution of calcium hydroxide was used. The $\mathrm{pH}$ value was adjusted with sodium hydroxide to value 13. This solution simulates the environment of fresh concrete. Sodium chloride was always added at the same concentration, while corrosion inhibitors were added in two concentrations. During the experiment, concentration of $0.423 \mathrm{~mol} \mathrm{l}^{-1}$ and $2.115 \mathrm{~mol} \mathrm{l}^{-1}$ was used. This concentration was determined from the critical chloride content for activation of corrosion process. The value of critical chloride content is 0.4 weight $\%$ of chloride anions per cement, while at normal humidity concentration of chloride anions will be $15 \mathrm{~g} \mathrm{l}^{-1}$ in concrete pore solution. The individual concentrations of chloride anions and inhibitors are shown in Tab. 1.

Tab. 1. Chemical composition of individual solutions / Chemické zloženie jednotlivých roztokov

\begin{tabular}{|c|c|c|}
\hline Solution & Cl$^{-}$content & Inhibitor content \\
\hline \multirow{2}{*}{$\mathrm{Ca}(\mathrm{OH})_{2}$} & $15 \mathrm{~g} \mathrm{l}^{-1}$ & $1: 1\left(0.423 \mathrm{~mol} \mathrm{l}^{-1}\right)$ \\
\hline \multirow{5}{*}{$\mathrm{CaCO}_{3}$} & $0 \mathrm{~g} \mathrm{l}^{-1}$ & \multirow{3}{*}{$1: 1\left(2.115 \mathrm{~mol} \mathrm{l}^{-1}\right)$} \\
\hline & $0.1 \mathrm{~g} \mathrm{l}^{-1}$ & \multirow{3}{*}{$\left.10.423 \mathrm{~mol} \mathrm{l}^{-1}\right)$} \\
\cline { 2 - 2 } & $0.3 \mathrm{~g} \mathrm{l}^{-1}$ & \\
\cline { 2 - 2 } & $1 \mathrm{~g} \mathrm{l}^{-1}$ & \\
\hline & $3 \mathrm{~g} \mathrm{l}^{-1}$ & \\
\cline { 2 - 2 } & $10 \mathrm{~g} \mathrm{l}^{-1}$ & \\
\hline
\end{tabular}

\section{Electrochemical measurements}

Corrosion cells from polypropylene were fastened (app. $10 \mathrm{ml}$ ) onto the non-corroded steel specimens (Fig. 2). These cells were progressively filled with different solutions. First, the saturated calcium hydroxide solution (FCPS - fresh concrete pore solution) was tested. The passivation ability in a highly alkaline environment was first studied. After 24 hours, polarization resistance was measured, and corrosion cells were emptied. Subsequently, corrosion cells were filled with a new solution that content chloride anions (FCPS + chloride). Again after 24 hours, polarization resistance was measured and the procedure repeated, but solution was replaced by a new solution, which contained chloride anions and one of the corrosion inhibitors (FCPS + 
chloride $+1: 1$ or $5: 1$ inhibitor). Organic inhibitors were added to solutions in quantities corresponding to the ratio of molar concentrations $1: 1$ and 5:1 (corrosion inhibitor to chloride anion). For calcium carbonate (CCPS - carbonated concrete pore solution), procedure was same as in previous case. However, in this case, the efficiency of individual inhibitors in solution with different concentrations of chloride anions was monitored. Corrosion inhibitors were added in same concentration 1:1.

The electrochemical measurement performed in this study (at a room temperature of $25 \pm 1{ }^{\circ} \mathrm{C}$ ) included polarization resistance measurements. Prior to the electrochemical tests, the specimens were conditioned in the relevant testing solutions for 24 hours. A common three electrode arrangement was used. The steel specimen was used as the working electrode, platinum wire served as a counter electrode and as a reference electrode saturated calomel electrode (SCE) was chosen. The polarization resistance was performed in the potential range from $-0.2 \mathrm{~V}$ to $+0.2 \mathrm{~V}$ vs. open circuit potential $\left(\mathrm{E}_{\mathrm{oc}}\right)$ with scan rate $0.1 \mathrm{mV} / \mathrm{s}$. The value of polarization resistance was determined from the slope of the line in the range of $\pm 5 \mathrm{mV}$ from $\mathrm{E}_{\mathrm{oc}}$. Between the measurements, the corrosion cells were closed to prevent carbon dioxide from being absorbed from the air.

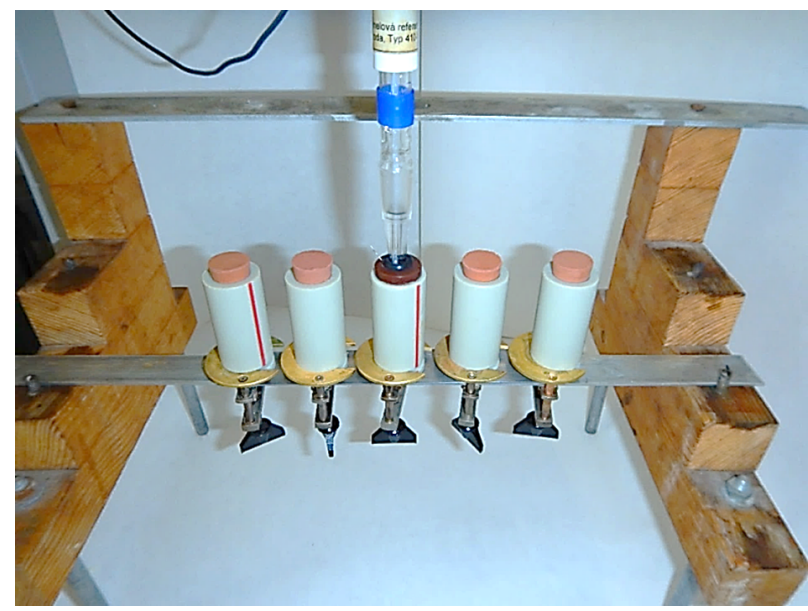

Fig. 2. Experimental arrangement

Obr. 2. Usporiadanie experimentu

\section{RESULTS AND DISCUSSION}

\section{Corrosive behavior of steel in a fresh concrete model solution}

Carbon steel in solution simulating fresh concrete showed high polarization resistance values approaching $100 \Omega \mathrm{m}^{2}$ after a 24 -hour exposure time. This points to the ability of carbon steel to passivate in fresh concrete without chloride anions. Such a magnitude of polarization resistance corresponds to an insignificant corrosion rate (the higher the polarization resistance, the lower the corrosion rate, $\mathrm{v}_{\text {cor }}=1 / \mathrm{Rp}$ ). Addition of chloride anions $\left(15 \mathrm{~g} \mathrm{l}^{-1}\right)$ to the model solution resulted in a decrease of polarization resistance value. This decrease in the polarization resistance value indicates that the steel has entered the active state (an increase of corrosion rate). By adding a corrosion inhibitor (concentration 1:1) to a chloride anions containing solution, it was assumed that the passive state of the steel could be restored. As shown in Figure 3, when corrosion inhibitors were added to the solution, the value of polarization resistance slightly increased to units of $\Omega \mathrm{m}^{2}$. Compared to CPS + chlorides, changes in the polarization resistance value are negligible. At a 5-times higher concentration of the corrosion inhibitor in the calcium hydroxide solution, changes in the polarization resistance values occurred. The polarization resistance of MA and TBAB increased slightly, but the polarization resistance values were still only in units of $\Omega \mathrm{m}^{2}$. Perhaps the most significant change was registered with the use of Guanidine carbonate, when the value of polarization resistance increased from units to tens of $\Omega \mathrm{m}^{2}$.

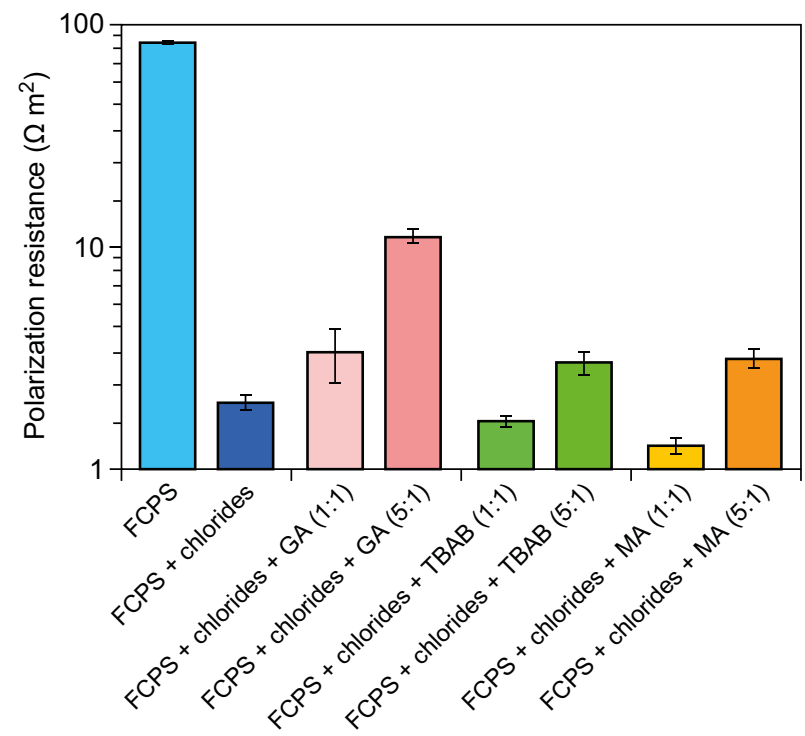

Fig. 3. Polarization resistance of steel specimens in FCPS with two levels of corrosion inhibitors and content $15 \mathrm{~g} \mathrm{l}^{-1}$ chlorides

Obr. 3. Polarizačná odolnost'ocel'ových vzoriek v FCPS s dvoma úrovňami koróznych inhibítorov a obsahom $15 \mathrm{~g} \mathrm{t}^{-1} \mathrm{chlo-}$ ridov

The passivity or activity of steel samples in individual simulated solutions within 24 hours of exposure was also monitored by means of open circuit potential. According to ASTM-C 876 [21], potentials are divided into three groups according to the probability of corrosion. On the Figure 4, the green colour area 
$(>-125 \mathrm{mV} / \mathrm{SCE})$ where the probability of $90 \%$ is not corrosion, grey colour area represents an intermediate risk of corrosive attack and red colour area $(<-270 \mathrm{mV} / \mathrm{SCE})$ responds to potentials at which the steel corrodes with a probability of $90 \%$.

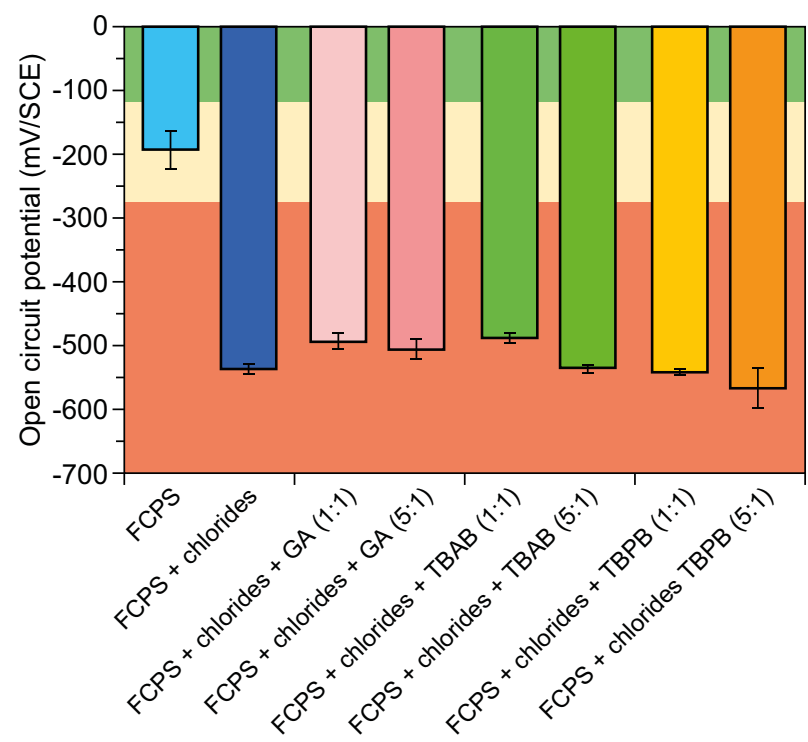

Fig. 4. Open circuit potential of steel specimens after $24 \mathrm{~h}$ exposure

Obr. 4. Samovolný korózny potenciál vzoriek po 24 h expozícii

\section{Corrosion behavior of steel in carbonated concrete model solution}

Carbonation had the same effect in terms of depassivation as an increase of chloride concentration in fresh concrete pore solution. At lower $\mathrm{pH}$, the polarization resistance dropped down to the order of units of $\Omega \mathrm{m}^{2}$, even though no chlorides were present (Fig. 5). The value of polarization resistance of about $30 \Omega \mathrm{m}^{2}$ is considered to be the threshold [22].

\section{Guanidine carbonate (GA)}

The results of polarization resistance show (Fig. 5) that the polarization resistance decreased progressively as chloride concentration in carbonated concrete pore solution increased. However, the values of polarization resistance remained in the order of tens of $\Omega \mathrm{m}^{2}$ even at concentration $1 \mathrm{~g} \mathrm{l}^{-1}$ of chloride anions. A significant effect of guanidine carbonate was observed in the study [16]. Sawada et al. [23, 24] used guanidine carbonate for electrochemical injection, were guanidine effectively injected into carbonated cement paste at depths corresponding to normal cover thicknesses to reinforcing steel.

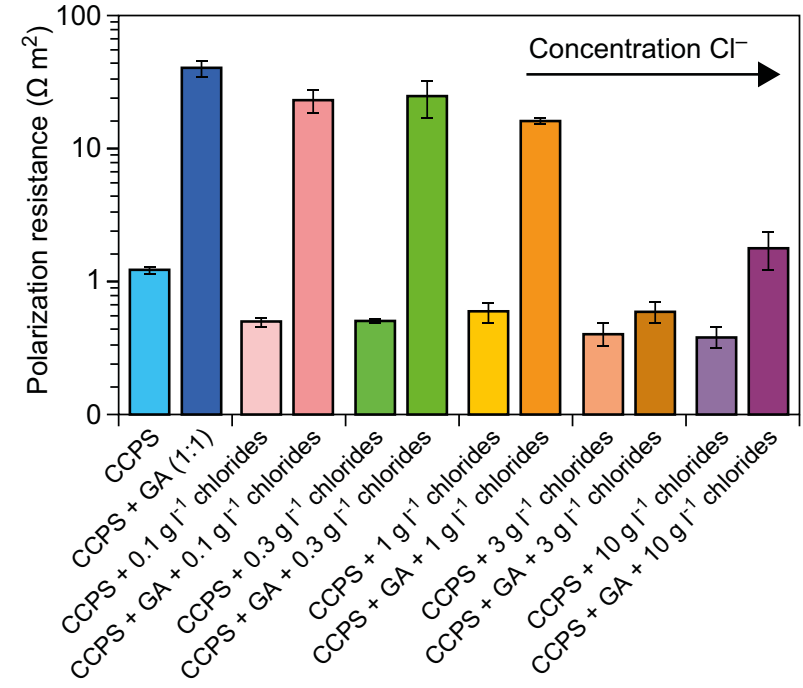

Fig. 5. Polarization resistance of steel specimens in CCPS with different level of chlorides and content guanidine carbonate

Obr. 5. Polarizačná odolnost' ocelových vzoriek v CCPS $s$ rôznymi koncentráciami chloridov a obsahom guanidín karbonátu

\section{Methylamine (MA)}

Methylamine showed low values of polarization resistance in fresh concrete, but in a solution of carbonated concrete its values of polarization resistance are similar to those obtained when guanidine carbonate was used (Fig. 6). At a concentration of $1 \mathrm{~g} \mathrm{l}^{-1}$ of chloride ions, the values of polarization resistance were in the tens of $\Omega \mathrm{m}^{2}$. Subsequently, the values of polarization resistance dropped sharply at the concentration more than $1 \mathrm{~g} \mathrm{l}^{-1}$.

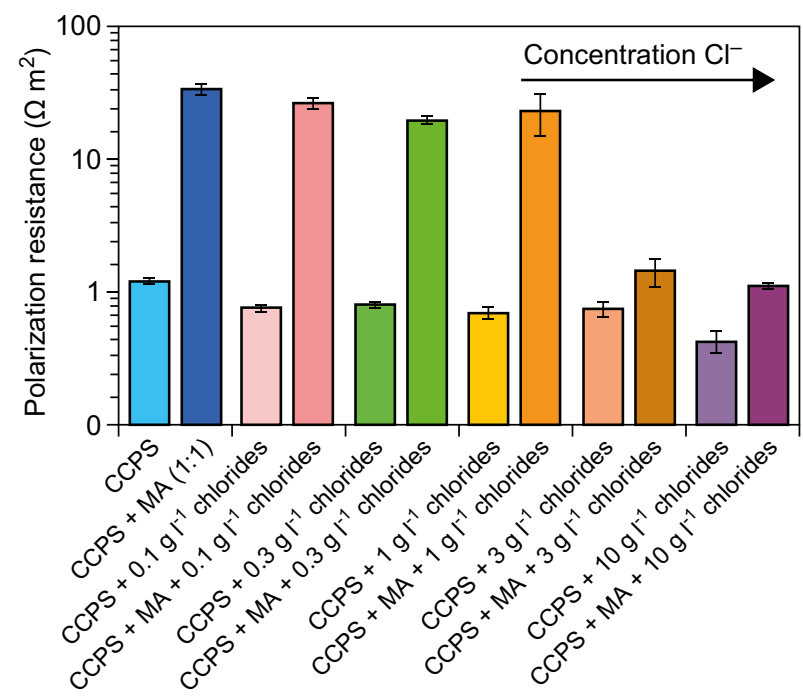

Fig. 6. Polarization resistance of steel specimens in CCPS with different level of chlorides and content methylamine Obr. 6. Polarizačná odolnost' ocel'ových vzoriek v CCPS s rôznymi koncentráciami chloridov a obsahom metylamínu 


\section{Tetrabutylammonium bromide (TBAB)}

The TBAB showed no inhibitory effects even in chloride-free solution (Fig. 7). The polarization resistance values are in the range of 1.1 to $0.5 \Omega \mathrm{m}^{2}$. Nguyen et al. [25] used TBAB for electrochemical treatment. Treatment was carried out by using a constant current density with alkaline solution containing corrosion inhibitor. They received promising results by means of polarization resistance test. There is no similar effect in our tests. The main reason may be the presence of bromides. Since bromide belongs to the group of aggressive elements, it is also $\mathrm{Cl}$ or $\mathrm{S}$. These may result in more aggressive substances in the solution which interfere with the formation of a passive layer on the steel surface. The final result is therefore a solution of $0.423 \mathrm{~mol} \mathrm{l}^{-1}$ of bromides to which $\mathrm{Cl}$ is still attached. Pan et al. [26] reduced the corrosion rate of the steel by 85 percent.by using TBAB in the simulated concrete pore solution.

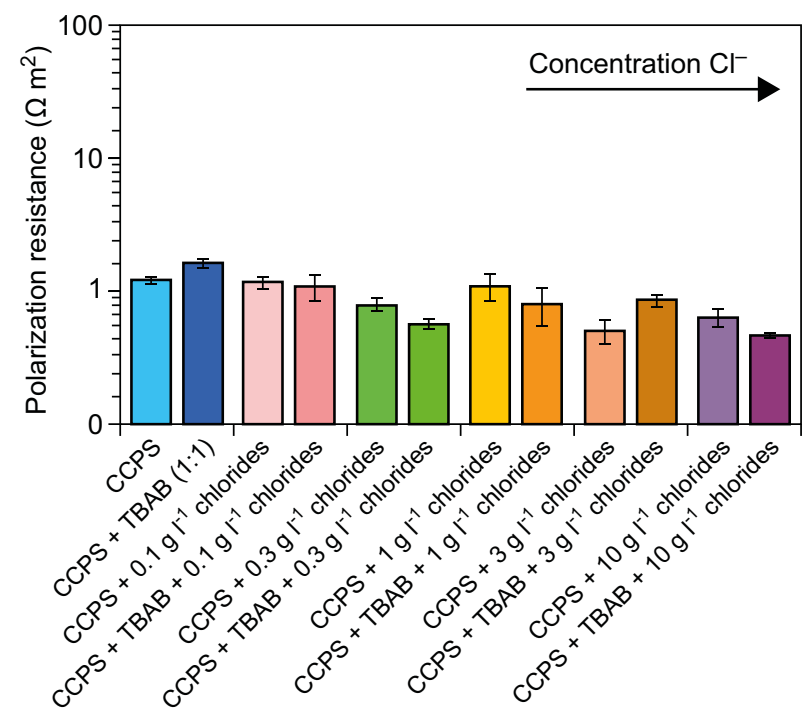

Fig. 7. Polarization resistance of steel specimens in CCPS with different level of chlorides and content tetrabutylammonium bromide

Obr. 7. Polarizačná odolnost' ocel'ových vzoriek v CCPS s rôznymi koncentráciami chloridov a obsahom tetrabutylammoniumbromidu

\section{CONCLUSION}

The measured data showed that none of the corrosion inhibitors showed significant inhibition properties in the chlorine-containing fresh pore solution, although some inhibition was observed. The inhibition effects in the carbonated concrete were observed to a concentration of chloride ions of $1 \mathrm{~g} \mathrm{l}^{-1}$ for guanidine carbonate and methylamine. With consequent increase of chloride concentration, the ability of corrosion inhibitors decreases radically. There was no significant difference between individual corrosion inhibitors. Tetrabutylammonium bromide has been ineffective in both the fresh concrete model solution and the carbonated concrete model solution, however, it is assumed, that the inhibitor's effectiveness was influenced by the presence of bromides, which have similar effect as chloride anions.

What remains unanswered is whether the transport of such a corrosion inhibitors might be accelerated by electrochemical injection to chloride contaminated and/ or carbonated concrete while extracting chlorides and/or re-alkalizing the concrete surrounding the depassivated steel.

\section{Acknowledgments}

The authors gratefully acknowledge the support by the Czech Science Foundation in the frame of the research project 16-11879S.

\section{REFERENCES}

1. Mundra, A., et al., Chloride-induced corrosion of steel rebars in simulated pore solutions of alkali-activated concretes. Cement and Concrete Research 2017, 100, 385-397.

2. Angst, U. M., et al., Chloride induced reinforcement corrosion: Electrochemical monitoring of initiation stage and chloride threshold values. Corrosion Science 2011, 53, 1451-1464.

3. Lovasi, T., Msallamova, S., Kouril, M., Jamborova, T., Stoulil, J., Nemecek, J., Sulc, R. Cathionic corrosion inhibitors for protection of steel in chloride contaminated concrete. In METAL 2017: $26^{\text {rd }}$ International Conference on Metallurgy and Materials. Brno, 2017, pp. 1361-1367.

4. Chang, Ch. F., Chen, J. W., The experimental investigation of concrete carbonation depth. Cement and Concrete Research 2006, 36, 1760-1767.

5. Ibrahin, M., et al., Effectiveness of concrete surface treatment materials in reducing chloride-induced reinforcement corrosion. Construction and Building Materials 1997, 11, 443-451.

6. Collins, W. D., et al., Chemical Treatment of Corroding Steel Reinforcement after Removal of Chloride-Contaminated Concrete. Corrosion 1993, 49 (1), 74-88.

7. Webb, N. C., Cathodic protection of reinforced concrete. Construction and Building Materials 1992, 6 (3), 179-183.

8. Pedeferri, P., Cathodic protection and cathodic prevention. Construction and Building Materials 1996, 10, 391-402.

9. Lambert, P., Cathodic protection of reinforced concrete. Anti-Corrosion methods and Materials 1995, 42, 4-5.

10. Berkeley, K. G. C., and S. Pathmanaban. Cathodic Protection of Reinforcement Steel in Concrete. Boston: Butterworths, 2000.

11. Živica, Vladimír. Referencing: Elektrochemické postupy pre sanáciu korodovaných železobetónových konštrukcií. 
iMateriály [online]. 2008. https://imaterialy.dumabyt.cz/ rubriky/poruchy/elektrochemicke-postupy-pre-sanaciukorodovanych-zelezobetonovych-konstrukcii_101507. html (accessed 11 Jan 2019)

12. Orellan, J. C., et al., Electrochemical chloride extraction: efficiency and side effects. Cement and Concrete Research 2004, 34, 227-234.

13. Liu, Y., et al., Electrochemical Chloride Extraction and Electrochemical Injection of Corrosion Inhibitor in Concrete: State of the Knowledge. Corrosion Reviews 2011 , 27, 53-82.

14. Fajardo, G., et al., Electrochemical chloride extraction (ECE) from steel-reinforced concrete specimens contaminated by "artificial" sea-water. Corrosion Science 2006, 48, 110-125.

15. Kubo, J., et al., Application of electrochemical organic corrosion inhibitor injection to a carbonated reinforced concrete railway viaduct. Construction and Building Materials 2013, 39, 2-8.

16. Karthick, S. P., et al., Electrochemical process to improve the durability of concrete structures. Journal of Building Engineering 2016, 7, 273-280.

17. Kubo, J., et al., Electrochemical inhibitor injection for control of reinforcement corrosion in carbonated concrete. Materials and Corrosion 2008, 59 (2), 107 -114.

18. Mangaiyarkarasi, G., Muralidharan, S., Electrochemical Protection of Steel in Concrete to Enhance the Service Life of Concrete Structures. Procedia Engineering 2014, $86,615-622$.
19. Kouril, M., Lovasi, T.; Msallamova, S.; Nemecek, J.; Sulc, R. Electrochemical injection of cathionic corrosion inhibitors. In ACSEE 2017. Sixth International Conference on Advances in Civil, Structural and Environmental Engineering. Rome, 2017, pp. 40-44.

20. https://online.ferona.cz/detail/23985/plech-valcovany-zastudena-k-tvareni-za-studena-en-10131-rozmer-2x1250x 2500 (accessed 11 Jan 2019)

21. ASTM C876-15. Standard Test Method for Corrosion Potentials of Uncoated Reinforcing Steel in Concrete. West Conshohocken, PA: ASTM International, 2015. 8 p.

22. Novak, P., Mala, R. Comparison of electrochemical data and mass loss corrosion rate measurements for steel reinforcement in concrete. European Federation of Corrosion Publications 2000, 31, 41-48.

23. Sawada, S., et al., Electrochemical injection of organic corrosion inhibitors into carbonated cementitious materials: Part 1. Effects on pore solution chemistry. Corrosion Science 2007, 49, 1186-1204.

24. Sawada, S., et al., Electrochemical injection of organic corrosion inhibitors into concrete. Corrosion Science 2005, 47, 2063-2078.

25. Nguyen, T. H., et al., Effect of Electrical Injection of Corrosion Inhibitor on the Corrosion of Steel Rebar in Chloride-Contaminated Repair Mortar. International Journal of Corrosion 2015, 1-10.

26. Pan, T., et al., Assessment of Electrical Injection of Corrosion Inhibitor for Corrosion Protection of Reinforced Concrete. TRB Annual Meeting 2008, Washington D.C. 